Acta vet. scand. $1970,11,604-605$.

Brief communication

\title{
DIFFERENTIATION OF KERATEIN FROM BOVINE AND CANINE HAIR BY PASSIVE HEMAGGLUTINATION*)
}

The possibility of keratein species differentiation was examined using the passive hemagglutination test. To the knowledge of the author this approach has not previously been attempted. Keratein was obtained by solubilizing hairs cut from a Jersey cow and a cross-bred dog in disodium sulfide and urea (Goddard \& Michaelis 1934). After precipitation with acetic acid the kerateines were redissolved in $0.1 \mathrm{~N}-\mathrm{NaOH}$ and dialyzed for 48 hrs. against $0.1 \mathrm{M}-\mathrm{Na}_{2} \mathrm{HPO}_{4}, \mathrm{pH} \mathrm{9.0}$. The nitrogen content was determined by micro $\mathrm{Kjeldahl}$ analysis and the keratein content calculated by multiplying the nitrogen figure with the factor 6.25. Antisera against the 2 kerateines were produced in adult rabbits. These were injected with approx. $5 \mathrm{mg}$ keratein once a week for 3 weeks. A $5 \mathrm{mg}$ booster dose was given 4 weeks after the third injection. The potency of the antisera was tested by immuno double diffusion in $1 \%$ agar gel. Suitable sera were used for the passive hemagglutination test (Stavitsky 1954). Goat erythrocytes were coated with the 2 respective kerateines using approx. $0.1 \mathrm{mg}$ keratein per $\mathrm{ml}$ of a $2.5 \%$ erythrocyte suspension. After inactivation at $56^{\circ} \mathrm{C}$ for $30 \mathrm{~min}$. and absorption with 2 volumes of packed goat erythrocytes the antisera were absorbed 3 times with equal volumes of the heterologous keratein containing approx. $0.5 \mathrm{mg}$ protein per $\mathrm{ml}$. Serial 2-fold dilutions of the respective antisera were prepared in $1 \%$ normal rabbit serum in $0.85 \%$ saline. The keratein coated erythrocytes were then suspended in the absorbed and diluted homologous and heterologous antisera. The tests were read after incubation at $20^{\circ} \mathrm{C}$ for 3 to $4 \mathrm{hrs}$. From the results listed in Table 1 it may be seen that the hemagglutination titers of the homologous sy-

*) Supported by a grant from Statens jordbrugs- og veterinærvidenskabelige Forskningsråd. 
T a b l e 1. Serum titers of hemagglutination.

\begin{tabular}{|c|c|c|}
\hline $\begin{array}{l}\text { Goat erythrocytes } \\
\text { coated with: }\end{array}$ & $\begin{array}{c}\text { Anti bovine } \\
\text { keratein serum }\end{array}$ & $\begin{array}{c}\text { Anti canine } \\
\text { keratein serum }\end{array}$ \\
\hline Bovine keratein & & \\
\hline 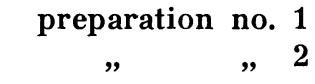 & $\begin{array}{l}1: 3200 \\
1: 3200\end{array}$ & $\begin{array}{l}<1: 20 \\
<1: 20\end{array}$ \\
\hline 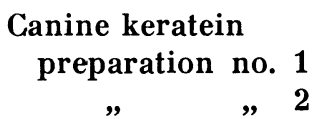 & $\begin{array}{l}<1: 20 \\
<1: 20\end{array}$ & $\begin{array}{l}1: 3200 \\
1: 6400\end{array}$ \\
\hline
\end{tabular}

stems are more than $\mathbf{1 0 0}$-fold above their heterologous counterparts.

Thus a significant differentiation has been achieved between kerateines from the 2 species. The observations indicate that a reliable keratein species differentiation may be accomplished on the basis of the passive hemagglutination test.

\section{H. B. Simonsen,}

The Department of Forensic and State Veterinary Medicine, Royal Veterinary and Agricultural University,

Copenhagen, Denmark.

\section{REFERENCES}

Goddard, R. D. \& L. Michaelis: A study on keratin. J. biol. Chem. 1934, $106,605-614$.

Stavitsky, A. B.: Micromethods for the study of proteins and antibodies. J. Immunol. 1954, 72, 360-375.

(Received November 10, 1970). 